\begin{tabular}{|c|c|c|}
\hline Dinamika Journal, Vol. 1 No. 3, 2019 \\
ISSN ONLINE : 2686-2158
\end{tabular}

\title{
EDUKASI DETEKSI DINI RADIKALISME BAGI SANTRI DI PESANTREN DARUL ABROR PURWOKERTO
}

\author{
Rindha Widyaningsih $^{1^{*}}$, Kuntarto ${ }^{1}$, Muhamad Riza Chamadi \\ ${ }^{1}$ Fakultas Ilmu Budaya, Universitas Jenderal Soedirman, Purwokerto \\ ${ }^{2}$ Fakultas Biologi, Universitas Jenderal Soedirman, Purwokerto \\ *Corresponding author: reindha 84@yahoo.co.id \\ Received 10 August 2019; Accepted 25 October 2019; Available online 28 October 2019
}

\begin{abstract}
Abstrak
Kegiatan pengabdian kepada masyarakat edukasi deteksi dini radikalisme bagi santri di Pondok Pesantren Darul Abror Purwokerto bertujuan untuk memberikan pemahaman dan pengetahuan para santri mengenai radikalisme dan bagaimana melakukan deteksi dini radikalisme pada level individu maupun kelompok. Kegiatan dilakukan sebanyak 8 (delapan) sesi dengan melibatkan 50 (lima puluh) peserta. Metode yang dilakukan adalah dengan memberikan materi menggunakan metode pendidikan partisipatif yang melibatkan peserta dan pemateri secara aktif. Jenis kegiatan yang dilakukan antara lain berupa (1) Pemberian materi edukasi, (2) Diskusi, dan (3) Pra test dan Post test untuk membandingkan pemahaman dan pola pikir peserta antara sebelum dan sesudah diberi edukasi. Hasil kegiatan menunjukkan adanya perubahan yang signifikan terhadap pemahaman dan pola pikir peserta mengenai radikalisme dan deteksi dini radikalisme.
\end{abstract}

Kata Kunci: radikalisme, edukasi, santri

\begin{abstract}
Community service education for early detection of radicalism for students at Darul Abror Islamic Boarding School in Purwokerto aims to provide understanding and knowledge of students about radicalism and how to do early detection of radicalism at individual and group level. The activity was carried out as many as 8 (eight) sessions involving 50 (fifty) participants. The method used is to provide material using participatory education methods that actively involve participants and presenters. The types of activities carried out include (1) Provision of educational material, (2) Discussion, and (3) Pre-Test and Post-Test to compare participants' understanding and mindset between before and after being given education. The results showed that there were significant changes in the participants' understanding and mindset regarding radicalism and the early detection of radicalism.
\end{abstract}

Keywords: radicalism; education; religious person, students of islamic school student 


\section{PENDAHULUAN}

Indonesia adalah Negara yang memiliki kerentanan yang tinggi bagi tumbuh dan berkembangnya radikalisme. Diproyeksikan penduduk Indonesia yang berpotensi melakukan tindakan radikal pada tahun mendatang jumlahnya mencapai 7,7 persen dari jumlah total penduduk Indonesia atau mencapai 11 juta jiwa (Widyaningsih, et al., 2017). Proyeksi tersebut mendekati kenyataan dengan semakin meningkatnya kasus aksi radikal dan jumlah pelaku aksi radikal atau simpatisan kelompok radikal yang selalu mengalami kenaikan dari tahun ke tahun.

Kabupaten Banyumas memiliki potensi yang tinggi bagi tumbuh dan berkembangnya paham radikalisme yang disebabkan karena faktor geografis, karakteristik masyarakat, dan perilaku keberagamaan masyarakatnya. Kelompok usia yang memiliki kerawanan tinggi terpengaruh dan terpapar paham radikalisme adalah Generasi muda, dan terutama pelajar dan mahasiswa, terlebih di Banyumas terdapat banyak perguruan tinggi dan sekolah (Widyaningsih et al., 2017).

Ideologi radikal banyak diadopsi dan dikembangkan oleh individu perseorang maupun melalui organisasi-organisasi resmi. Ideologi radikal ini banyak menyusupi generasi muda melalui organisasi-organisasi lewat jalur kampus dan SMA. Ideologi radikal agama kini bahkan merambah di sektor bisnis/industri ke sektor swasta/bisnis melalui pekerja-pekerja pabrik, Aparatur Sipil Negara bahkan hingga di tubuh aparat kepolisian dan TNI. Di dalam masyarakat ideologi radikal ini juga menyusup dalam berbagai majelis taklim, pengajian, musholla, organisasi agama dan kegiatan-kegiatan kegamaan yang lain.

Penelitian Badan Nasional Penanggulangan Terorisme menemukan bahwa persebaran paham radikal di lingkungan kampus telah terjadi setidaknya sejak 30 tahun yang lalu. Penelitian ini sekaligus memperkuat penelitian yang dilakukan oleh Alvara Research Center pada Oktober 2017 yang menyebutkan 23,5 persen menyetujui gerakan Negara Islam Irak dan Suriah. Selain itu, 23,4 persen menyetujui kesiapan untuk berjihad mendirikan khilafah. Penelitian ini melibatkan 1.800 responden di 25 universitas se-Indonesia (Rahma, 2019).

Persebaran ideologi radikal semakin cepat, mudah, efektif, dan berbiaya murah dengan memanfaatkan perkembangan ilmu pengetahuan dan teknologi, terutama teknologi informasi. Teknologi dengan masif mengamplifikasi ideologi radikal di zaman digital seperti sekarang. Para agen paham radikal tidak harus bertemu dengan sasarannya atau menggelar diskusi untuk mengagitasi mereka. Propagandis radikalisme cukup menarik calon korban ke grup Telegram dan WhatsApp, lalu mencuci otak mereka dengan ideologi-ideologi sesat.

Kehadiran internet merupakan Keberadaan organisasi kampus seringkali dimanfaatkan bagi para agen kelompok radikal untuk merekrut anggota baru.Posisi strategis mahasiswa dan siswa yang mempunyai jangkauan pergaulan luas dan relatif otonom, dianggap oleh gerakan radikal sebagai sarana yang paling pas dan mudah untuk memproliferasi paham-paham radikal yang mereka perjuangkan (Fanani, 2013). Pondok pesantren adalah salah satu aspek pendidikan yang menjadi andalan dalam mencetak generasi bangsa yang memiliki kompetensi tinggi yang disertai dengan akhlak religius dan terpuji.Sistem pendidikan di pesantren yang menekankan pembelajaran agama secara komprehensif dan kontekstual merupakan formulasi mencegah paham-paham radikal menyebar (Syafe'i, 2017). Namun demikian potensi penyebaran paham radikal bukan mustahil terjadi mengingat para santri juga berinteraksi di kampus, masyarakat luas, dan terkoneksi dengan internet.

Ideologi radikal menyusup dan mempengaruhi anak muda dengan cara yang halus, menarik, dan mampu menumbuhkan rasa ingin tahu. Pada banyak kasus ditemukan ideologi- 
ideologi radikal menyusup melalui kegiatan kegamaan maupun mengintrusi organisasiorganisasi keagamaan kampus (Ismail, 2016). Seringkali anak muda terjebak pada ideologi radikal tanpa mereka sadari karena mereka menganggap yang mereka pelajari adalah ajaran agama yang sebenarnya. Melalui doktrinasi secara terus menerus anak-anak muda yang memiliki semangat tinggi ini secara tidak sadar diarahkan untuk memiliki pola pikir dan bahkan hingga menjadi pelaku aksi radikal.

Dalam kegiatan pengabdian kepada masyarakat ini difokuskan di Pondok Pesantren.Alasan dipilihnya pesantren karena Pondok Pesantren adalah lembaga studi agama yang mempunyai nilai historis terhadap gerakan sosial keagamaan.Pondok Pesantren berperan aktif dalam kehidupan sosial masyarakat termasuk politik. Implikasinya Pondok Pesantren juga menjadi target politik kekuasaan dan menjadi rentan dipengaruhi oleh paham-paham kekerasan yang terbalut agama (Satori \& Kusmayadi, 2018).

Pondok Pesantren Darul Abror merupakan lembaga pendidikan yang berbasis Islam yang terletak di Desa Watumas, Kelurahan Purwanegara, Kecamatan Purwokerto Utara, Kabupaten Banyumas, Provinsi Jawa Tengah.Kehadiran Pondok Pesantren Darul Abror memiliki arti penting bagi masyarakat di Purwokerto dan sekitarnya karena menjadi sarana pembelajaran agama dari berbagai daerah dan memiliki kurikulum dan sistem pembelajaran yang jelas, tersktuktur, dan sistematis.

Pondok Pesantren Darul Abror didirikan oleh Kyai Taufiqurrahman beserta tokoh masyarakat sekitar tahun 1997. Dari tahun ke tahun Pondok Pesantren Darul Abror terus mengalami perubahan mulai dari bertambahnya santri, perbaikan administrasi, dan Dewan Asatidz. Santri yang belajar di Pondok Pesantren Darul Abror Watumas Purwanegara Purwokerto Utara sebagian besar terdiri dari mahasiswa dan juga pelajar dari tingkatan MI, MTs, hingga SMA. Jumlah santri putra dan putri mencapai hingga 500 lebih santri yang dibagi menjadi empat kelas Madin (Madrasah Diniah) diantaranya kelas Ibtida, kelas I, kelas II, dan kelas III.

Pondok Pesanten Darul Abror memiliki arti penting bagi masyarakat sekitar karena selain menjadi tempat belajar bagi para santri, Darul Abror juga menjaditempat berkumpulnya masyarakat Watumas Purwanegara dengan berbagai macam kegiatan seperti: pengajian ibu-ibu, yasinan bapak-bapak, Taman Pendidikan Al Qur'an (TPQ), serta pendidikan kitab-kitab klasik.

Santri yang ada di Pondok Pesantren Darul Abror memiliki kerentanan yang tinggi terpengaruh paham radikal, karena mereka muda, pintar, kondisi psikologis yang relatif masih labil, dan rawan dibujuk dengan menggunakan dalih agama. Kekhawatiran ini semakin menguat manakala pada tahun 2018 lalu ada seorang santri di Pondok Pesantren Darul Abror yang diketahui menghilang secara misterius dan belum diketahui keberadaaanya hingga kini oleh pengurus ponpes maupun oleh keluarga. Menurut wawancara yang dilakukan kepada pengasuh dan pengurus Pondok Pesantren Darul Abror, kuat dugaan bahwa santri tersebut terpengaruh paham radikal dan memilih meninggalkan ponpes demi mengikuti kelompok radikal tersebut.

Kondisi ini menimbulkan keprihatinan sekaligus menyadarkan kita bahwa generasi muda sangatlah rentan terpengaruh paham radikalisme. Menilik dari angka kasus radikalisme yang semakin meningkat dari tahun ke tahuan, menunjukkan upaya pencegahan paham radikalisme haruslah dilakukan secara masif, serius, dan melibatkan semua aspek dan struktur masyarakat.

Salah satu metode pendekatan intrusi ideologi radikal adalah melalui pembelajaran agama.Agama dijadikan sebagai kamuflase untuk menarik minat dan perhatian anak muda yang sedang bersemangat mempelajari ilmu agama. Di masa kini agama menjadi alat propaganda untuk menyebarkan ideologi radikal dan paham kekerasan (Abdullah, 2016). Ideologi radikal 
senantiasa mengincar anak muda Indonesia dengan cara-cara yang inovatif, kreatif, dan terusmenerus melalui segala lini massa. Mengamati hal tersebut maka memberikan Pengetahuan dan pemahaman mengenai deteksi dini radikalisme adalah hal yang krusial untuk dilakukan secara komprehensif, berkelanjutan, dan massif.

\section{METODE PELAKSANAAN}

Kegiatan Edukasi Deteksi Dini Radikalisme bagi santri di Pondok Pesantren Darul Abror Purwokerto dilakukan dengan menggunakan metode pendidikan masyarakat.Kegiatan dilakukan dengan menggunakan metode pendidikan partisipatif yang melibatkan peserta dan pemateri secara aktif.Jenis kegiatan yang dilakukan antara lainberupa (1) Pemberian materi edukasi, (2) Diskusi, dan (3) Pra test dan Post test untuk membandingkan pemahaman dan pola pikir peserta antara sebelum dan sesudah diberi edukasi.

Kegiatan pengabdian diikuti oleh santri Pondok Pesantren Darul Abror sejumlah 50 (lima puluh) peserta yang bertempat di Pondok Pesantren Darul Abror Purwokerto. Kegiatan pengabdian dilaksanakan selama tiga hari, yaitu tanggal 10-12 Juli 2019. Materi yang disampaikan dalam edukasi Deteksi Dini Radikalisme dibagi dalam 8 (Delapan) sesi dengan rincian sebagai berikut:

1. Sesi 1: Materi yang diberikan adalah Pembukaan dan Pra test

2. Sesi 2: Materi yang diberikan adalah Pemahaman dasar radikalisme

3. Sesi 3: Materi yang diberikan adalah Sejarah radikalisme dan radikalisme agama

4. Sesi 4: Materi yang diberikan adalah Gambaran radikalisme di Kabupaten Banyumas

5. Sesi 5: Materi yang diberikan adalah Ciri dan penyebaran radikalisme

6. Sesi 6: Materi yang diberikan adalah Faktor penyebab dan sumber radikalisme

7. Sesi 7: Materi yang diberikan adalah Pancasila sebagai penangkal radikalisme

8. Sesi 8: Materi yang diberikan adalah Post test dan Penutup

Materi yang disampaikan pada kegiatan pengabdian didasarkan atas hasil penelitian yang telah dilakukan pada tahun sebelumnya oleh Tim pengabdian yang terdiri dari 3 (tiga) orang dosen yang memiliki latar belakang keilmuan Agama dan Pancasila.

Sebelum program pelatihan dilaksanakan, akan dilakukan Pra-test untuk mengukur pemahaman santri tentang radikalisme dan kemampuan melakukan deteksi dini individu atau kelompok yang terpapar paham radikal. Selama program pelatihan akan dilaksanakan evaluasi pada setiap akhir kegiatan untuk memonitoring kemampuan peserta. Evaluasi dapat berupa pemberian pertanyaan terkait dengan topik pelatihan yang sudah dilakukan, dan diskusi interaktif terkait materi untuk memperdalam pemahaman.Di akhir kegiatan dilaksanakan Post-test untuk mengukur kembali peningkatan pengetahuan dan efektivitas pelaksanaan edukasi para santri yang sudah mengikuti kegiatan edukasi, sehingga dapat diketahui apakah terjadi peningkatan pengetahuan tentang radikalisme dan deteksi dini radikalisme.

Ukuran keberhasilan dari kegiatan pengabdian Deteksi Dini Radikalisme adalah para santri mengalami peningkatan pengetahuan mengenai radikalisme dan Para santri mampu melakukan deteksi dini terhadap kelompok radikal atau individu yang terpapar paham radikal. 


\section{HASIL DAN PEMBAHASAN}

\section{A. Tahap Kegiatan}

Kegiatan pengabdian kepada masyarakat diawali dengan koordinasi dan perancangan kegiatan yang melibatkan pengurus Pondok Pesantren Darul Abror dan Tim Pengabdian. Pelaksanaan kegiatan edukasi dilakukan sebanyak 8 (delapan) sesi dengan durasi masing-masing pertemuan selama 3 (tiga) jam dengan jumlah peserta sebanyak 50 (lima puluh) orang.

1. Persiapan Kegiatan

Kegiatan pertemuan pertama diawali dengan pembukaan, pembacaan ayat Al Quran, dan perkenalan dengan Tim Pengabdian yang dilanjutkan dengan menjabarkan rancangan dan rencana kegiatan. Pada sesi ini para peserta diminta untuk melakukan Pra test untuk mengukur tingkat pengetahuan dan pemahaman mengenai radikalisme dan deteksi dini radikalisme.

Materi Pra test terdiri dari 27 (dua puluh tujuh) pertanyaan yang digunakan sebagai indikator untuk mengukur pemahaman radikalisme dan kemampuan deteksi dini radikalisme. Aspek yang diukur untuk mengetahui pemahaman tentang radikalisme dan deteksi dini ditampilkan dalam tabel berikut:

Tabel 1. Aspek Pengukuran

\begin{tabular}{ll}
\hline \multicolumn{1}{c}{ Pemahaman Radikalisme } & \multicolumn{1}{c}{ Deteksi Dini Radikalisme } \\
\hline Pemahaman dasar radikalisme & Jenis-jenis radikalisme \\
$\begin{array}{l}\text { Contoh kasus gerakan/kelompok radikal } \\
\text { Tokoh yang terlibat gerakan/kelompok }\end{array}$ & Ciri individu terpapar radikalisme \\
radikal/terorisme & Ciri individu terpapar radikalisme \\
Bahaya radikalisme & Sumber penyebab munculnya radikalisme \\
Cara menangkal radikalisme & Cara penyebaran radikalisme \\
\hline
\end{tabular}

2. Edukasi pemahaman radikalisme

Kegiatan pengabdian kepada masyarakat dilakukan dengan pemberian materi edukasi dengan tema "Pemahaman Dasar Radikalisme". Materi diberikan oleh Tim Pengabdian sebanyak 3 (tiga) sesi dengan menggunakan media LCD dan proyektor. Pada sesi materi pemahaman radikalisme para peserta diberi pengetahuan perbedaan dari fundamentalisme, radikalisme, dan terorisme. Materi berikutnya peserta diberikan contoh mengenai kasus gerakan radikalisme dan contoh kelompok maupun tokoh-tokoh yang terlibat gerakan radikalisme. Tahapan berikutnya peserta diberi pemahaman mengenai bahaya radikalisme dan cara-cara yang dapat dilakukan untuk menangkal radikalisme, terutama yang mengincar kalangan anak muda.

Sesi terakhir pada tahap edukasi pemahaman radikalisme berupa diskusi dan tanya jawab antara peseta terkait dengan materi yang telah diberikan. Pertanyaan evaluasi diberikan kepada peserta untuk semakin memantapkan pengetahuan dan pemahaman peserta mengenai materi yang telah disampaikan.

\section{Deteksi dini radikalisme}

Kegiatan pengabdian kepada masyarakat pada tahap berikutnya dilakukan sebanyak 3 (tiga) sesi dimana peserta diberi edukasi mengenai deteksi dini radikalisme. Dalam Materi deteksi dini radikalisme peserta diberikan pengetahuan dan pemahaman mengenai jenis-jenis 
radikalisme, bagaimanakah ciri-ciri individu dan kelompok yang terindikasi terpapar paham radikal, sumber penyebab munculnya radikalisme, dan cara-cara penyebaran paham radikal.

Dalam sesi ini peserta diperlihatkan video yang digunakan untuk memperjelas materi yang disampaikan. Materi diberikan secara interaktif dengan membuka sesi diskusi dan tanya jawab antara peserta dan pemateri. Pertanyaan evaluasi diberikan di akhir sesi untuk semakin memantapkan materi.

\section{Penutup dan Post test}

Setelah melalui 6 (enam) sesi materi yang berlangsung dengan durasi kegiatan masingmasing sesi selama 3 (tiga) jam, kegiatan dilanjutkan dengan penutupan secara resmi. Kegiatan terakhir yang dilakukan pada kegiatan pengabdian kepada masyarakat adalah dengan melakukan Post test untuk mengetahui peningkatan pemahaman dan pengetahuan peserta.

\section{B. Hasil Kegiatan}

Untuk mengetahui tingkat pemahaman peserta dilakukan dengan membandingkan hasil Pra test dan Post test. Aspek penilaian dalam edukasi deteksi dini radikalisme ini dapat dilihat dalam tabel berikut:

1. Pemahaman Radikalisme

Tabel 2. Perubahan Tingkat Pemahaman Radikalisme

\begin{tabular}{llclc}
\hline Tingkat Pengetahuan & \multicolumn{1}{c}{ Sebelum Edukasi } & & Setelah Edukasi \\
\hline Sangat Tahu & 0 & $0 \%$ & 10 & $20 \%$ \\
Tahu & 0 & $0 \%$ & 40 & $80 \%$ \\
Cukup Tahu & 35 orang & $70 \%$ & 0 & 0 \\
Tidak Tahu & 15 orang & $30 \%$ & 0 & 0 \\
\hline
\end{tabular}

2. Pengetahuan Contoh Kasus Radikalisme

Tabel 3. Perubahan Pengetahuan Contoh Kasus Radikalisme

\begin{tabular}{llclc}
\hline Tingkat Pengetahuan & \multicolumn{1}{c}{ Sebelum Edukasi } & & Setelah Edukasi \\
\hline Sangat Tahu & 0 & $0 \%$ & 50 & $100 \%$ \\
Tahu & 0 & $0 \%$ & 0 & $0 \%$ \\
Cukup Tahu & 35 orang & $70 \%$ & 0 & 0 \\
Tidak Tahu & 15 orang & $30 \%$ & 0 & 0 \\
\hline
\end{tabular}

3. Pemahaman Ciri Terpapar Radikalisme

Tabel 4. Perubahan Pemahaman Ciri Terpapar Radikalisme

\begin{tabular}{llclc}
\hline Tingkat Pengetahuan & \multicolumn{2}{c}{ Sebelum Edukasi } & & Setelah Edukasi \\
\hline Sangat Tahu & 0 & $0 \%$ & 12 & $24 \%$ \\
Tahu & 0 & $0 \%$ & 38 & $76 \%$ \\
Cukup Tahu & 20 orang & $40 \%$ & 0 & 0 \\
Tidak Tahu & 30 orang & $60 \%$ & 0 & 0 \\
\hline
\end{tabular}


4. Pemahaman Sumber Munculnya Radikalisme

Tabel 5. Perubahan Tingkat Pemahaman Munculnya Radikalisme

\begin{tabular}{llclc}
\hline Tingkat Pengetahuan & \multicolumn{2}{c}{ Sebelum Edukasi } & \multicolumn{1}{c}{ Setelah Edukasi } \\
\hline Sangat Tahu & 0 & $0 \%$ & 5 & $10 \%$ \\
Tahu & 0 & $0 \%$ & 45 & $90 \%$ \\
Cukup Tahu & 15 orang & $30 \%$ & 0 & 0 \\
Tidak Tahu & 35 orang & $70 \%$ & 0 & 0 \\
\hline
\end{tabular}

5. Pemahaman Cara Penyebaran Radikalisme

Tabel 6. Perubahan Tingkat Pemahaman Cara Penyebaran Radikalisme

\begin{tabular}{llclc} 
Tingkat Pengetahuan & \multicolumn{1}{c}{ Sebelum Edukasi } & & Setelah Edukasi \\
\hline Sangat Tahu & 0 & $0 \%$ & 19 & $38 \%$ \\
Tahu & 0 & $0 \%$ & 31 & $62 \%$ \\
Cukup Tahu & 10 orang & $20 \%$ & 0 & 0 \\
Tidak Tahu & 40 orang & $80 \%$ & 0 & 0 \\
\hline
\end{tabular}

6. Pemahaman Bahaya Radikalisme

Tabel 7. Perubahan Tingkat Pemahaman Bahaya Radikalisme

\begin{tabular}{llclc} 
Tingkat Pengetahuan & \multicolumn{1}{c}{ Sebelum Edukasi } & & Setelah Edukasi \\
\hline Sangat Tahu & 0 & $0 \%$ & 25 & $50 \%$ \\
Tahu & 0 & $0 \%$ & 25 & $50 \%$ \\
Cukup Tahu & 45 orang & $90 \%$ & 0 & 0 \\
Tidak Tahu & 5 orang & $10 \%$ & 0 & 0 \\
\hline
\end{tabular}

7. Pemahaman Cara Menangkal Radikalisme

Tabel 8. Perubahan Tingkat Pemahaman Cara Menangkal Radikalisme

\begin{tabular}{llclc} 
Tingkat Pengetahuan & \multicolumn{1}{c}{ Sebelum Edukasi } & & Setelah Edukasi \\
\hline Sangat Tahu & 0 & $0 \%$ & 6 & $12 \%$ \\
Tahu & 0 & $0 \%$ & 44 & $88 \%$ \\
Cukup Tahu & 17 orang & $34 \%$ & 0 & 0 \\
Tidak Tahu & 33 orang & $66 \%$ & 0 & 0 \\
\hline
\end{tabular}

Berdasarkan hasil perbandingan Pra test dan Post test dapat diketahui pemahaman radikalisme peserta mengalami kenaikan pengetahuan menjadi sangat tahu sebanyak $20 \%$ dan tahu sebanyak $80 \%$. Peningkatan pemahaman ini meliputi membedakan antara fundamentalisme, radikalisme dan terorisme, serta mampu mebedakan dan mengetahui definisi dari ketiga istilah tersebut.

Pengetahuan contoh kasus radikalisme mengalami kenaikan pengetahuan tertinggi, yaitu menjadi sangat tahu sebanyak 100\%. Pada edukasi deteksi dini banyak diberikan contoh kasuskasus radikalisme baik yang bersifat lokal, nasional dan transnasional, sehingga pengetahuan dan pemahaman peserta mengenai contoh kasus radikalisme mengalami kenaikan paling signifikan.

Pemahaman peserta mengenai ciri-ciri terpapar radikalisme yang semula berada pada angka $40 \%$ cukup tahu, dan $60 \%$ tidak tahu mengalami kenaikan pengetahuan menjadi sangat tahu sebanyak $24 \%$ dan tahu sebanyak $76 \%$. Peserta diberi edukasi untuk mengidentifikasi seseorang atau sekelompok orang yang terpapar radikalisme yang dilihat dari ciri-ciri perilaku dan relasi sosial yang ditampilkan. 
Sebelum mendapatkan edukasi pemahaman peserta mengenai sumber munculnya radikalisme berada pada angka $30 \%$ cukup tahu dan $70 \%$ tidak tahu. Setelah mendapatkan edukasi mengenai faktor-faktor penyebab munculnya radikalisme baik yang berasal dari internal maupun eksternal, peserta mengalami kenaikan pengetahuan menjadi sangat tahu sebanyak $10 \%$ dan tahu sebanyak $90 \%$.

Edukasi cara penyebaran radikalisme menunjukan hasil peningkatan pengetahuan yang semula $20 \%$ cukup tahu, dan bahkan $80 \%$ tidak tahu, mengalami kenaikan pengetahuan menjadi sangat tahu sebanyak 38\% dan tahu sebanyak $62 \%$. Peserta diberi edukasi bahwa penyebaran radikalisme dapat muncul melalui berbagai cara dan media, terutama yang memanfaatkan kecanggihan teknologi informasi.

Kemampuan peserta untuk mengetahui bahaya radikalisme mengalami kenaikan pengetahuan setelah mendapatkan edukasi menjadi sangat tahu sebanyak 50\% dan menjadi tahu sebanyak 50\%. Angka ini mengalami kenaikan dibandingkan sebelum diberi edukasi, yaitu 90\% peserta semula cukup tahu, dan 10\% lainnya bahkan tidak tahu. Para peserta semula menganggap bahwa bahaya radikalisme hanya sekedar kerusakan pada objek-objek vital dan hilangnya nyawa korban saja. Setelah mendapatkan edukasi pemahaman mereka menjadi meningkat bahwa radikalisme menyimpan bahaya yang jauh lebih luas, besar, dan kompleks.

Pemahaman peserta mengenai cara menangkal radikalisme juga mengalami kenaikan pengetahuan menjadi sangat tahu sebanyak $12 \%$ dan tahu sebanyak $88 \%$. Angka ini mengalami kenaikan dibandingkan sebelum diberi edukasi yang hanya berkisar pada angka 34\% cukup tahu dan $66 \%$ tidak tahu. Peserta diberi edukasi cara-cara untuk menangkal radikalisme yang dimulai dari level individu hingga level komunitas.

\section{KESIMPULAN}

Kegiatan pengabdian kepada masyarakat yang dilakukan di Pondok Pesantren Darul Abror merupakan wujud partisipasi Tim pengabdi dalam pembangunan masyarakat melalui penerapan keilmuan yang dimiliki. Kegiatan edukasi deteksi dini radikalisme ini bertujuan untuk memberikan pengetahuan dan pemahaman kepada peserta yang berasal dari santri Darul Abror Purwokerto yang dimulai dari pemahaman dasar radikalisme, contoh-contoh kasus radikalisme baik yang bersifat lokal, nasional, dan transnasional, ciri-ciri individu dan kelompok yang terpapar radikalisme, sumber kemunculan radikalisme baik yang bersifat internal maupun eksternal, cara-cara penyebaran radikalisme, bahaya-bahaya yang ditimbulkan dari radikalisme, hingga cara menangkal radikalisme.

Secara umum edukasi deteksi dini yang dilakukan mendapatkan respon yang baik dan mampu meningkatkan pemahaman peserta mengenai radikalisme. Hal ini dapat dilihat dari angka Post test yang menunjukkan peningkatan angka yang signifikan di semua aspek. Kegiatan semacam ini hendaknya dapat dilakukan secara kontinyu dan berkesinambungan di semua lapisan masyarakat agar mampu memperkuat ketahanan ideologi bangsa sehingga mampu mencegah radikalisme. 


\section{DAFTAR PUSTAKA}

Abdullah, A. (2016). Gerakan Radikalisme Dalam Islam: Perspektif Historis. Addin, 10(1), 1. https://doi.org/10.21043/addin.v10i1.1127

Fanani, A. F. (2013). Fenomena Radikalisme di Kalangan Kaum Muda. Maarif, 8(1), 4-13.

Ismail, A. (2016). New Religious Movement On Campus: A Role Of Mosques In Raising Exclusivity. Analisa, 1(Juni 1), 41-58.

Rahma, A. (2019). Kemenristekdikti Akui Kampus Rentan Terpapar Radikalisme. Tempo.Co.

Satori, A., \& Kusmayadi, E. (2018). Pendidikan Bela Negara Bagi Santri Pesantren Di Cikalong Kabupaten Tasikmalaya. 2(2).

Syafe'i, I. (2017). Pondok Pesantren: Lembaga Pendidikan Pembentukan Karakter. AlTadzakiyyah, 8(Mei), 85-103.

Widyaningsih, R., Sumiyem, S., \& Kuntarto, K. (2017). The Potential of Religious Radicalism Movement in Banyumas. Walisongo: Jurnal Penelitian Sosial Keagamaan, 25(1), 203. https://doi.org/10.21580/ws.25.1.1807 